Pragmatism Ascendent 



\section{Pragmatism Ascendent}

A Yard of Narrative, A Touch of Prophecy

\section{Joseph Margolis}

Stanford University Press

Stanford, California 
Stanford University Press

Stanford, California

(C) 2012 by the Board of Trustees of the Leland Stanford Junior University.

All rights reserved.

No part of this book may be reproduced or transmitted in any form or by any means, electronic or mechanical, including photocopying and recording, or in any information storage or retrieval system without the prior written permission of Stanford University Press.

Printed in the United States of America on acid-free, archival-quality paper

Library of Congress Cataloging-in-Publication Data

Margolis, Joseph, 1924- author.

Pragmatism ascendent : a yard of narrative, a touch of prophecy / Joseph

Margolis.

pages $\mathrm{cm}$

Includes bibliographical references and index.

ISBN 978-0-8047-8227-2 (cloth : alk. paper) — ISBN 978-0-8047-8228-9 (pbk. : alk. paper)

I. Pragmatism-History. 2. Philosophy, American. 3. Philosophy, European.

4. Analysis (Philosophy) 5. Continental philosophy. I. Title.

B832.MI96 2013

I $44^{\prime} \cdot 3$ - dc23

2012014038

Typeset by Bruce Lundquist in II/I5.5 Adobe Garamond 
the global is never the universal 
